\title{
Pengembangan media pembelajaran video teranimasi pada materi elastisitas untuk siswa kelas X SMA
}

\author{
Efitra Nindy Frima Yonansa, Sentot Kusairi*, Purbo Suwasono \\ Universitas Negeri Malang, Jl. Semarang No. 5 Malang, Jawa Timur, Indonesia \\ *Penulis korespondensi, Surel: sentot.kusairi.fmipa@um.ac.id
}

Paper received: 01-08-2021; revised: 15-08-2021; accepted: 31-08-2021

\begin{abstract}
Abstrak
Masalah yang sering terjadi pada pembelajaran fisika adalah tidak semua siswa dapat menangkap apa yang disampaikan oleh guru. Program remedial yang direncanakan oleh guru ternyata sering terkendala oleh keterbatasan waktu sehingga siswa perlu belajar mandiri. Upaya membuat ketertarikan siswa untuk belajar mandiri adalah memanfaatkan media pembelajaran yang bersifat audio visual dalam bentuk video teranimasi. Tujuan penelitian ini adalah mengembangkan media pembelajaran video teranimasi pada materi elastisitas untuk siswa kelas X SMA. Penelitian ini menggunakan metode Borg and Gall dengan mengambil tujuh tahap meliputi analisis kebutuhan, perencanaan pembuatan rancangan produk, pengembangan bentuk produk awal, evaluasi ahli, melakukan uji coba kelompok kecil, revisi produk, dan hasil jadi produk. Produk hasil pengembangan terdiri atas empat file video yang masing-masing memuat pembukaan, materi inti, contoh soal dan pembahasan, uji diri siswa, penutup, petunjuk penggunaan untuk guru, dan petunjuk penggunaan untuk siswa. Analisis data berdasarkan data uji validasi dan uji coba terbatas secara keseluruhan diperoleh skor rata-rata sebesar 86,1 persen, sehingga memenuhi kategori layak.
\end{abstract}

Kata kunci: Media Pembelajaran; Video Teranimasi; Elastisitas.

\section{Pendahuluan}

Pembelajaran Fisika dapat tercapai apabila representasi objek pengamatan dapat dihadirkan di dalam kelas. Pengamatan secara langsung bertujuan untuk meningkatkan kualitas belajar siswa karena mereka mendapatkan pengalaman langsung dengan apa yang dipelajari sehingga belajar yang dihasilkan tidak mudah dilupakan. Pencapaian kualitas pembelajaran merupakan tanggung jawab seorang guru dan dosen melalui penciptaan pengalaman belajar yang bermakna bagi siswa atau mahasiswa dan fasilitas yang didapat siswa atau mahasiswa untuk mencapai hasil belajar yang maksimal (Sutikno, 2007). Pengalaman yang dimaksudkan berupa bekal untuk memperoleh pengetahuan baru atau mengembangkan pengetahuan yang telah dimilikinya sehingga siswa tahu pentingnya fisika dan dapat mengaplikasikannya dalam kehidupan sehari-hari.

Kenyataan yang sering ditemui di lapangan terkadang tidak sesuai dengan apa yang diharapkan. Guru sering menemui kendala atau bahkan tidak memiliki cukup waktu untuk menghadirkan objek pengamatan di dalam kelas sehingga guru menyampaikan materi Fisika dengan ceramah dan siswa hanya mendengarkan. Seringkali pelajaran Fisika disajikan dalam bentuk teori, rumus-rumus Fisika, dan mengutamakan perhitungan daripada penjelasan manfaat konsep-konsep Fisika dalam kehidupan sehari-hari. Hal ini mengakibatkan ilmu Fisika tereduksi menjadi bacaan dan siswa hanya dapat membayangkan. Selain itu konsepkonsep fisika akan terasa asing dalam kehidupan siswa sehingga pelajaran fisika dianggap pelajaran yang membosankan, tidak menarik, dan sulit dipahami.

Pada saat guru menjelaskan dengan metode ceramah, tidak semua siswa dapat menangkap apa yang disampaikan oleh guru. Siswa yang tergolong lambat dalam menguasai 
materi pembelajaran masih ada yang mengalami kesulitan ketika guru menjelaskan, apalagi jika guru hanya menjelaskan sekali saja. Untuk mengatasi masalah ini, guru diharapkan memberikan program remedial untuk siswa yang masih mengalami kesulitan. Remedial Teaching merupakan salah satu metode pembelajaran dalam upaya meningkatkan hasil belajar siswa terutama bagi siswa yang belum berhasil dalam hal pencapaian kompetensi (Depdiknas, 2003).

Upaya untuk membuat ketertarikan siswa untuk belajar mandiri adalah memanfaatkan media pembelajaran. Wahyudin (2010) menyatakan bahwa nilai dan kegunaan media pembelajaran dapat mempertinggi proses pembelajaran dan hasil belajar yang dicapai dalam proses pembelajaran. Salah satu media pembelajaran yang dapat digunakan untuk belajar mandiri adalah media yang bersifat audio visual. Dengan adanya visualisasi materi pembelajaran, siswa akan terbantu dalam mempelajari materi pembelajaran karena mudah ditangkap oleh panca indera. Visualisasi materi pembelajaran dapat diwujudkan dalam bentuk video teranimasi. Menurut Utami (2007) dalam Sakti (2013), animasi menjadi pilihan untuk menujang proses belajar yang menyenangkan dan menarik bagi siswa dan juga memperkuat motivasi, dan juga untuk menanamkan pemahaman pada siswa tentang materi yang diajarkan.

Beberapa penelitian telah dilakukan untuk mengembangkan media pembelajaran Fisika yang bersifat audio visual. Salah satunya adalah media pembelajaran Animated Video yang dikembangkan oleh Abyadati (2012). Media pembelajaran Animated Video yang dikembangkan memuat beberapa menu utama, yaitu Beranda, Materi dan Pengembang. Materi pada media ini adalah materi Fluida dengan Sub-materi Fluida Statis dan Fluida Dinamis. Hasil validasi media pembelajaran berdasarkan tingkat validitas media mencapai rata-rata 3,3 sedangkan menurut ahli materi sebesar 3,8. Jadi dapat disimpulkan bahwa media pembelajaran Animated Video yang dikembangkan sudah memenuhi kriteria layak dan selanjutnya dapat diujicobakan lebih luas.

Beberapa prinsip pembelajaran dalam kurikulum 2013 seperti yang dikutip dalam Kemendikbud (2013) antara lain: (1) Pembelajaran yang berlangsung di rumah, di sekolah, dan di masyarakat; dan (2) Pemanfaatan teknologi informasi dan komunikasi untuk meningkatkan efisiensi dan efektivitas pembelajaran. Dari kedua prinsip tersebut, video teranimasi merupakan media pembelajaran yang mencerminkan prinsip pembelajaran yang diharapkan dalam kurikulum 2013. Hal ini dapat dilihat dari sifat penggunaannya yang praktis, santai dan tidak terbatas tempat dan waktu memudahkan siswa menggunakannya setiap saat.

Media pembelajaran berupa video teranimasi merupakan gagasan yang dapat dijadikan solusi untuk mengatasi permasalahan pembelajaran yang tersebut di atas. Video merupakan salah satu jenis media yang digemari oleh siswa. Hal ini tidak terlepas dari kebiasaan siswa yang sering menonton film. Selain itu, ditunjang pula oleh sebagian besar siswa SMA memiliki telepon genggam dengan spesifikasi yang bagus. Hal ini merupakan peluang yang baik untuk mengembangkan video teranimasi sebagai media pembelajaran mandiri untuk membantu siswa dalam mengatasi kesulitan menguasai materi.

Berdasarkan pemikiran di atas, maka perlu dikembangkan media pembelajaran video teranimasi yang diharapkan dapat digunakan sebagai media dalam kegiatan pembelajaran fisika pada materi fisika di sekolah. 


\section{Metode}

Penelitian ini termasuk penelitian pengembangan yang menggunakan metode Borg \& Gall. Dari sepuluh tahap yang ada, peneliti mengambil tujuh tahapan yang ada, yaitu analisis kebutuhan, perencanaan pembuatan rancangan produk, pengembangan bentuk produk awal, evaluasi ahli, melakukan uji coba kelompok kecil, revisi produk, dan hasil jadi produk media pembelajaran.

Tahap awal yaitu analisis kebutuhan dilakukan analisis kebutuhan dilakukan melalui pengamatan dan pengumpulan informasi di SMAN 10 Malang. Analisis kebutuhan dilakukan melalui pengumpulan informasi di SMAN 10 Malang dengan mewawancarai salah satu siswa mengenai proses pembelajaran fisika. Pengamatan dan pengumpulan informasi ini bertujuan mengetahui media apa saja yang digunakan dalam pembelajaran fisika dan sejauh mana media tersebut mampu membantu siswa dalam belajar fisika. Pada tahap ini, peneliti juga mengumpulkan informasi terkait tentang media pembelajaran video teranimasi, software Camtasia Studio 8 sebagai perangkat lunak untuk membuat video teranimasi, dan materi elastisitas, kompetensi inti, dan kompetensi dasar elastisitas sesuai dengan kurikulum 2013. Tahap selanjutnya adalah merencanakan pembuatan rancangan produk. Setelah itu dilakukan pengembangan bentuk produk awal. Pengembangan awal produk dilakukan melalui software Microsoft Power Point 2010 dengan membuat slide presentasi yang dilengkapi dengan animasinya kemudian dijalankan menggunakan software Camtasia Studio 8 untuk memasukkan narasi dan instrumen musik di dalamnya. Media pembelajaran video teranimasi yang telah dibuat kemudian divalidasi atau dievaluasi oleh dua dosen dan satu guru fisika, dengan kualifikasi masing-masing merupakan ahli media dan ahli materi. Hasil penilaian terhadap media pembelajaran video teranimasi digunakan untuk memperbaiki kekurangannya. Media pembelajaran yang telah divalidasi selanjutnya diujicobakan secara terbatas kepada tujuh siswa SMA kelas X. Tahap selanjutnya adalah merevisi produk berdasarkan hasil uji coba terbatas.

Data yang dianalisis dalam penelitian ini adalah hasil penilaian oleh tim penilai pada angket yang telah disediakan. Jenis data yang diperoleh adalah data kuantitatif dan kualitatif. Data kuantitatif berupa nilai rata - rata angket. Data ini berupa angka 4, 3, 2, 1 berdasarkan Skala Likert. Sedangkan data kualitatif berupa komentar dan saran dari masing-masing validator. Teknik analisis yang digunakan untuk menganalisis data hasil validasi adalah perhitungan rata-rata. Berdasarkan pendapat dari Sugiyono (2013: 94-95), data interval dapat dianalisis dengan menghitung rata-rata jawaban berdasarkan skoring setiap jawaban dari responden dan validator.

\section{Hasil dan Pembahasan}

Pada bagian ini disajikan hasil pengembangan media pembelajaran video teranimasi. Media pembelajaran ini dikembangkan pada materi elastisitas yang digunakan untuk siswa kelas X SMA. Produk video teranimasi seluruhnya berjumlah empat video dengan ukuran frame width 1058 dan frame height 720. Pembagian sub materi pada video teranimasi ini meliputi (1) sifat elastis benda; (2) hukum Hooke; (3) tegangan, regangan, dan modulus Young; dan (4) susunan pegas.

Konten dalam video teranimasi elastisitas ini terdiri atas (a) pembuka; (b) judul sub materi yang akan dibahas; (c) materi inti; (d) contoh soal dan pembahasan; (e) uji diri siswa; dan (f) penutup. Pembuka video merupakan tampilan awal video yang berisi count-down, 
ucapan selamat datang, perkenalan singkat dari video yang dikembangkan, nama pengembang, nama pembimbing, instansi, tahun pengembangan, judul materi elastisitas, sasaran pengguna video, kompetensi dasar, dan beberapa gambar yang berhubungan dengan materi elastisitas. Bagian tampilan pembuka video teranimasi dapat dilihat pada Gambar 1 dan 2 berikut.

\section{Gambar 1 Tampilan Selamat Datang}

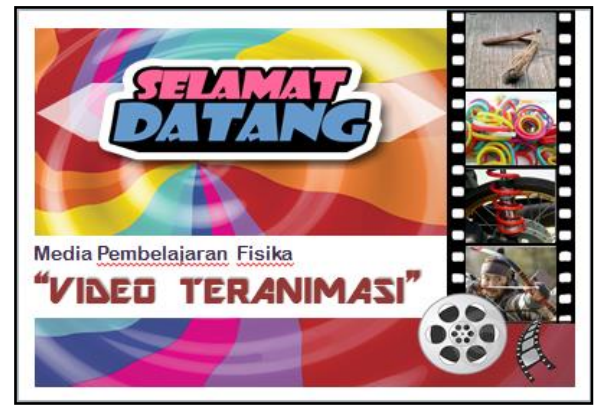

Gambar 2 Tampilan Judul Video Teranimasi

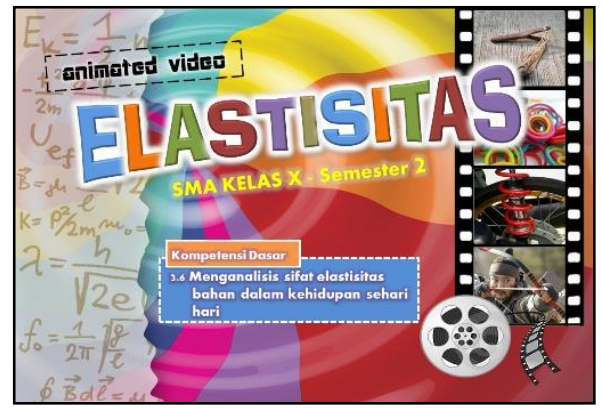

Bagian judul sub materi merupakan bagian video setelah tampilan pembuka video. Bagian ini menjelaskan judul sub materi yang akan menjadi topik pembahasan dalam video tersebut. Bagian tampilan sub materi video teranimasi dapat dilihat pada Gambar 3 berikut.

\section{Gambar 3 Tampilan judul sub materi video teranimasi}

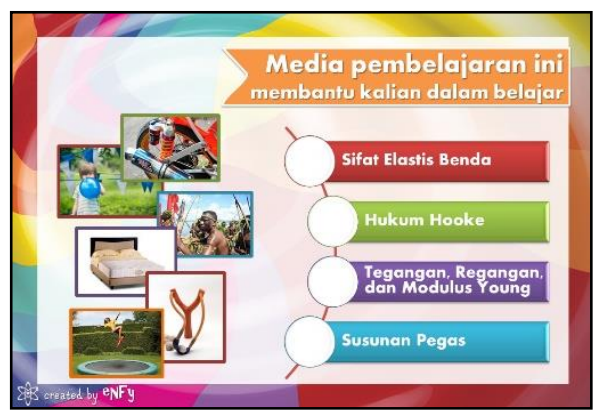

Sebelum masuk pada materi inti, disajikan fenomena yang mengantarkan pemahaman siswa pada konsep yang akan dipelajari. Setelah itu masuk pada inti materi yang berisi penjelasan materi, dan rumusan matematis tentang materi yang dibahas. Dalam penjelasan materi dilengkapi juga dengan gambar yang berkaitan dengan materi sehingga memudahkan siswa memahami konsep. Bagian materi inti dapat dilihat pada Gambar 4 berikut. 


\section{Gambar 4 Tampilan Penjelasan Materi}

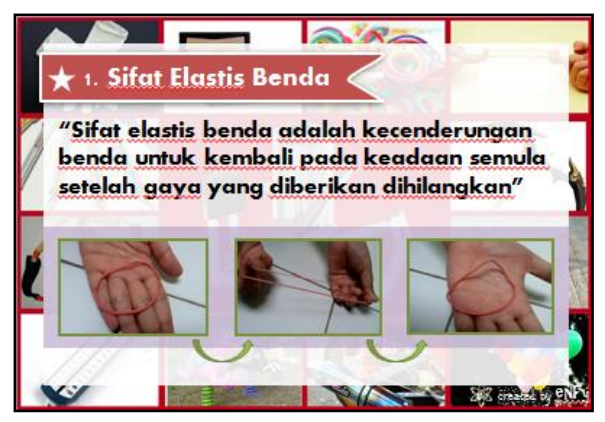

Pada setiap submateri disajikan satu contoh soal yang dilengkapi pula dengan gambar dan pembahasan. Dalam memperoleh jawaban, langkah-langkah pembahasan disajikan secara runtut untuk memudahkan siswa dalam mengerjakan soal yang serupa. Bagian contoh soal dan pembahasannya dapat dilihat pada Gambar 5 berikut.

\section{Gambar 5 Contoh Soal dan Pembahasan}

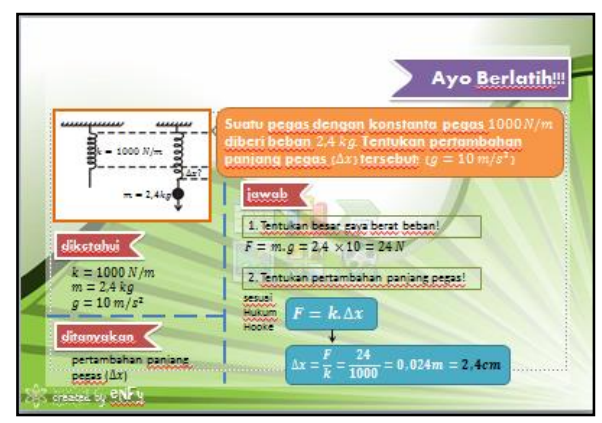

Uji diri siswa merupakan bagian yang bertujuan sebagai sarana yang digunakan siswa untuk mengasah kemampuannya setelah belajar menggunakan video teranimasi. Jenis soal dalam uji diri siswa terdiri atas soal pernyataan benar/salah dan soal pilihan ganda. Setelah disajikan butir soal, tersedia jeda waktu yang dapat digunakan siswa untuk berpikir dan menemukan jawabannya. Setelah itu disediakan pembahasan untuk memeriksa jawaban yang ditemukan oleh siswa sudah benar atau belum. Bagian uji diri siswa dapat dilihat pada Gambar berikut.

\section{Gambar 6 Uji Diri Siswa dengan Jenis Soal Benar/Salah}

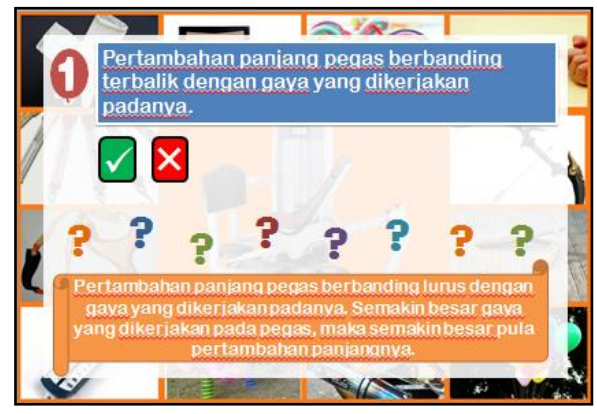




\section{Gambar 7 Uji Diri Siswa dengan Jenis Soal Pilihan Ganda}

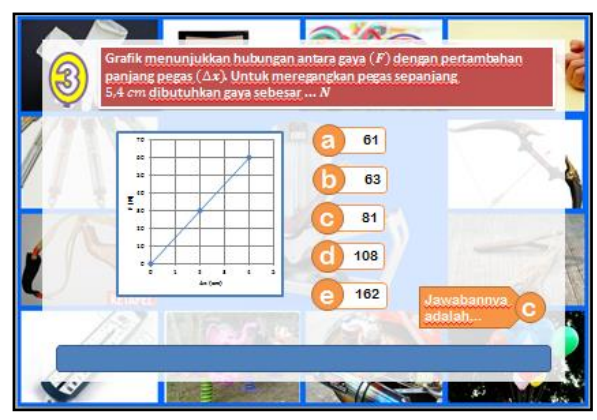

Bagian penutup merupakan bagian paling akhir video teranimasi. Bagian penutup ini memuat ucapan terimakasih telah menggunakan video untuk belajar serta mengajak siswa untuk belajar pada materi selanjutnya. Tampilan penutup video dapat dilihat pada Gambar 8 berikut.

\section{Gambar 8 Bagian Penutup}

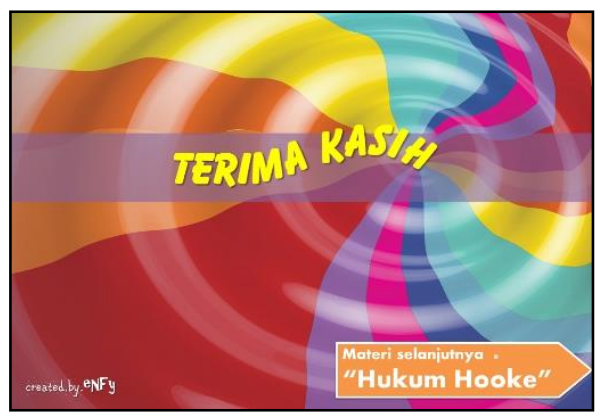

Petunjuk penggunaan untuk guru merupakan pedoman yang dipakai untuk guru dalam menggunakan media pembelajaran video teranimasi. Tampilan petunjuk penggunaan untuk guru dapat dilihat pada Gambar 9 berikut.

\section{Gambar 9 Petunjuk Penggunaan untuk Guru}

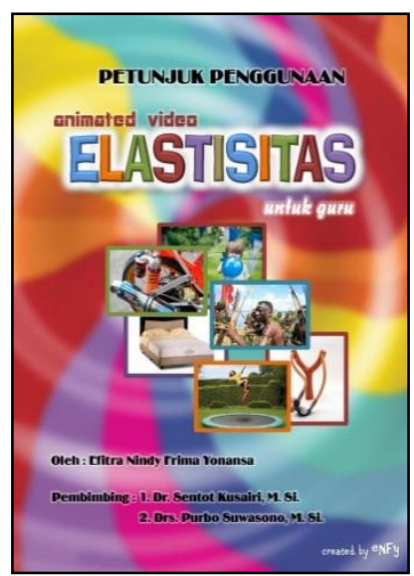

Petunjuk penggunaan untuk siswa merupakan pedoman yang dipakai untuk siswa dalam menggunakan media pembelajaran video teranimasi. Tampilan petunjuk penggunaan untuk siswa dapat dilihat pada Gambar 10 berikut. 


\section{Gambar 10 Petunjuk Penggunaan untuk Siswa}

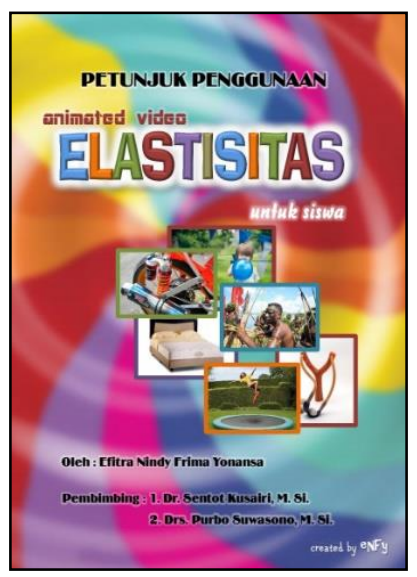

Berdasarkan hasil uji kelayakan dan uji coba terbatas yang telah dilakukan, diperoleh nilai kelayakan total dari tiap aspek pertanyaan oleh masing-masing validator dan siswa. Nilai kelayakan tersebut disajikan dalam Tabel 1 dan Gambar 11 berikut.

Tabel 1 Hasil Analisis Data Keseluruhan

\begin{tabular}{|l|l|l|l|}
\hline No. & Subjek & $\begin{array}{l}\text { Rata-rata Masing- } \\
\text { masing Subjek (\%) }\end{array}$ & Kategori \\
\hline 1 & $\begin{array}{l}\text { Validator konstruk } \\
\text { media pembelajaran }\end{array}$ & 88,6 & Layak \\
\hline 2 & $\begin{array}{l}\text { Validator isi media } \\
\text { pembelajaran }\end{array}$ & 85,3 & Layak \\
\hline 3 & $\begin{array}{l}\text { Siswa peserta uji coba } \\
\text { terbatas }\end{array}$ & 84,4 & Layak \\
\hline \multicolumn{2}{|r|}{ Rata-rata Keseluruhan } & 86,1 & Layak \\
\hline
\end{tabular}

Gambar 11 Hasil Analisis Data Keseluruhan

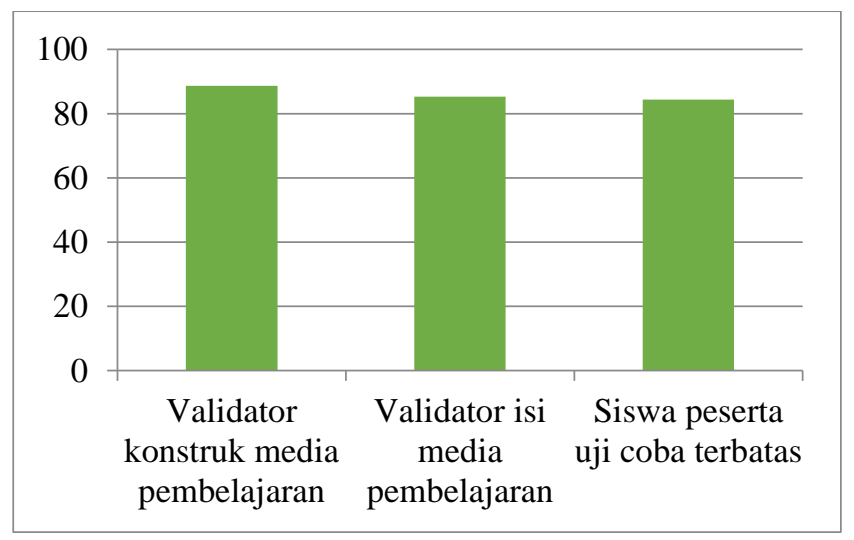

Analisis data pada media pembelajaran video teranimasi pada materi elastisitas untuk siswa kelas X SMA didasarkan pada hasil analisis rata-rata angket oleh validator konstruk, validator isi, dan tujuh siswa peserta uji coba terbatas. Berdasarkan data hasil kelayakan pada uji validasi dan uji coba terbatas tersebut secara keseluruhan diperoleh skor rata-rata media pembelajaran video teranimasi pada materi elastisitas untuk siswa kelas X SMA sebesar $86,1 \%$, sehingga memenuhi kategori layak. Dari hasil uji kelayakan dan uji coba 
terbatas tersebut dapat disimpulkan bahwa pengembangan media pembelajaran video teranimasi pada materi elastisitas untuk siswa kelas X SMA tidak memerlukan perbaikan yang signifikan. Namun masih terdapat beberapa bagian yang perlu diperbaiki, baik pada segi tampilan maupun kualitas audio dalam video teranimasi ini. Hal ini dilakukan untuk mengoptimalkan kualitas video sebagai media pembelajaran fisika sehingga dapat digunakan dengan maksimal. Perbaikan produk ini dilakukan berdasarkan komentar dan saran saat uji kelayakan dan uji coba terbatas. Perbaikan yang dilakukan dalam pengembangan media pembelajaran ini meliputi bagian tampilan pembukaan yang dibuat lebih sederhana, penggunaan kata dalam penjelasan materi, latar belakang video yang diganti sesuai topik elastisitas, dan pilihan jawaban serta pembahasan pada bagian uji diri siswa.

Video teranimasi dikembangkan sebagai media belajar yang fleksibel dalam penggunaan atau pengoperasiannya. Dengan bentuk file video, maka media ini tidak hanya dapat dioperasikan menggunakan PC namun juga dapat diputar melalui telepon genggam sehingga video teranimasi ini dapat dengan mudah diakses oleh siswa dimana pun dan kapan pun. Hal ini sesuai dengan pendapat Dick dan Carey dalam Sadiman (2010) bahwa faktor yang perlu dipertimbangkan dalam pemilihan media adalah menyangkut keluwesan, kepraktisan, dan ketahanan media yang bersangkutan untuk waktu yang lama.

\section{Simpulan}

\subsection{Kesimpulan}

Media pembelajaran yang dikembangkan berupa video teranimasi yang digunakan sebagai media pembelajaran mandiri oleh siswa kelas X SMA. Video teranimasi yang dikembangkan berjumlah empat video dengan judul sesuai dengan pembagian materinya, yaitu (1) sifat elastis benda; (2) hukum Hooke; (3) tegangan, regangan, dan modulus Young; dan (4) susunan pegas. Media pembelajaran yang dikembangkan mencakup kompetensi inti, yaitu memahami dan menerapkan pengetahuan faktual, konseptual, prosdural dalam ilmu pengetahuan, teknologi, seni, budaya, dan humaniora dengan wawasan kemanusiaan, kebangsaan, kenegaraan, dan peradaban terkait fenomena dan kejadian, serta menerapkan pengetahuan prosedural pada bidang kajian yang spesifik sesuai dengan bakat dan minatnya untuk memecahkan masalah. Materi yang dipilih adalah materi elastisitas yang termasuk dalam kompetensi dasar (KD) menganalisis sifat elastisitas bahan dalam kehidupan sehari-hari.

Berdasarkan hasil validasi yang telah dilakukan, ditinjau dari segi konstruk, secara kuantitatif memperoleh persentase $88,6 \%$ sedangkan ditinjau dari segi isi, secara kuantitatif memperoleh persentase $85,3 \%$. Hal ini berarti video teranimasi yang telah dikembangkan termasuk dalam kategori layak untuk digunakan sebagai media penunjang belajar siswa. Selain itu diperoleh pula penilaian secara kualitatif berupa komentar dan saran dari validator yang digunakan sebagai pertimbangan untuk memperbaiki media pembelajaran video teranimasi sebagai hasil akhir pengembangan produk yang lebih baik. Dari hasil uji coba terbatas yang telah dilakukan, diperoleh persentase rata-rata $84,4 \%$. Berdasarkan data hasil kelayakan pada uji validasi dan uji coba terbatas tersebut secara keseluruhan diperoleh skor rata-rata media pembelajaran video teranimasi pada materi elastisitas untuk siswa kelas X SMA sebesar 86,1\%, sehingga memenuhi kategori layak. Hal ini menunjukkan 
bahwa video teranimasi yang dikembangkan menarik untuk digunakan sebagai media penunjang belajar mandiri untuk siswa.

Kekuatan produk berdasarkan penggunaannya adalah pada jenis produk dengan bentuk video dengan format MP4 (*.mp4) yang dapat dijalankan baik menggunakan PC maupun menggunakan handphone dengan fitur yang sesuai. Dengan demikian, penggunaan produk akan bersifat lebih santai dan fleksibel. Kelemahan produk berkaitan dengan masalah latihan soal yang dirasa kurang oleh peneliti karena soal latihan dan pembahasan dibuat sebanyak mungkin agar siswa mendapat bahan belajar lebih banyak. Selain itu, kelemahan lain berkaitan dengan sifat produk yang tidak interaktif sehingga diperlukan proses editting lebih lanjut agar produk menjadi interaktif. Pengembangan yang dilakukan hanya sampai pada tahap uji coba terbatas dengan menyisakan tahap uji lapangan dan diseminasi karena keterbatasan waktu dan biaya yang digunakan. Selain itu, perlu pula dilakukan uji lebih lanjut karena uji coba hanya ditekankan pada segi konstruk saja. Serta kelemahankelemahan lain yang luput dari pengamatan peneliti.

\subsection{Saran}

Berdasarkan hasil uji kelayakan dan uji coba terbatas kepada siswa, media pembelajaran yang telah dikembangkan dinilai layak. Berdasarkan kajian revisi produk diketahui video teranimasi ini masih memiliki kekurangan, sehingga belum dapat langsung digunakan sebagai media pembelajaran oleh siswa, tetapi harus diuji lebih lanjut terlebih dahulu.

Media pembelajaran yang dikembangkan dapat digunakan sebagai salah satu acuan kepada peneliti yang lain untuk mengembangkan media pembelajaran dari kompetensi dasar yang berbeda maupun sama tetapi dengan beberapa perbaikan. Perbaikan yang dimaksud contohnya adalah mengadakan uji coba yang lebih luas dan melakukan uji lebih lanjut untuk mengetahui keefektifan produk. Proses editting lebih lanjut dengan perangkat lunak yang sesuai diperlukan agar produk bersifat interaktif. Selain itu perbaikan juga dapat dilakukan dengan meningkatkan kualitas audio dengan teknik dan perangkat rekaman yang lebih baik. Saran yang dapat diberikan untuk diseminasi produk adalah dengan menyebarkannya kepada guru-guru fisika dan siswa kelas X SMA yang membutuhkan media pendamping belajar. Selain itu, diseminasi produk juga dapat dilakukan dengan meida internet dengan mengunggah video ke youtube, blog, dan website. Untuk melanjutkan pada tahap yang lebih luas, hendaknya memperhatikan kelemahan dan memperbaiki kekurangan yang ada.

\section{Daftar Rujukan}

Abyadati, s. (2013). Pengembangan media pembelajaran fisika animated video (video teranimasi) materi fluida untuk SMA kelas XI. skripsi Jurusan Fisika-Fakultas MIPA UM.

Pendidikan, M. (2013). Peraturan Menteri Pendidikan dan Kebudayaan Republik Indonesia Nomor 65 Tahun 2013 tentang standar proses pendidikan dasar dan menengah. Jakarta: Pemerintah Republik Indonesia.

Makmun, Abin Syamsuddin. (2007). Psikologi Kependidikan. Bandung: Remaja Rosdakarya.

Sadiman, A. S., Rahardjo, R., \& Haryono, A. (2003). Media pendidikan: pengertian, pengembangan dan pemanfaatannya. 
Sakti, I. (2013). Pengaruh media animasi fisika dalam model pembelajaran langsung (direct instruction) terhadap minat belajar dan pemahaman konsep fisika siswa di SMA Negeri Kota Bengkulu. Prosiding SEMIRATA 2013, 1(1).

Sugiyono, P. D. (2013). Metode penelitian manajemen. Bandung: Alfabeta, CV.

Sukmadinata Nana, S. (2010). Metode Penelitian Pendidikan. Bandung: Remaja Rosdakarya.

Sutikno, M. S. (2007). Menggagas Pembelajaran Efektif dan Bermakna. Jakarta: NTP Press Mataram.

Wahyudin, -., Sutikno, -., \& Isa, A. (2010). Keefektifan pembelajaran berbantuan multimedia menggunakan metode inkuiri terbimbing untuk meningkatkan minat dan pemahaman siswa. Jurnal pendidikan fisika indonesia, 6(1). doi:https://doi.org/10.15294/jpfi.v6i1.1105 